Notes

\title{
Alex Philip, The Graphic Press, and Canada’s First All-Talking Picture $^{\mathrm{I}}$
}

\section{Carole Gerson*}

During the heady years preceding the Vancouver/Whistler Winter Olympics of 2oIo, I looked into Whistler's literary history in the hope of finding early writing that was worth reprinting, analogous to my Vancouver Short Stories ${ }^{2}$, which had been endorsed by the cultural arm of Vancouver's Centennial Commission in commemoration of the city's hundredth birthday in 1986. Alex Philip quickly emerged from the archive, but his pulp novels proved less notable than other aspects of his career. The spotty record of the production and reception of his sensational Western fiction offers intriguing glimpses into several dusty corners of Canada's book history and cultural history because he published two books with Graphic Press and because one of his novels became "Canada's First All-talking Picture" (see Figure I). ${ }^{3}$

I I would like to thank my colleague, Peter Dickinson, for advice about researching Canada's film history and Alan Twigg, editor of BC Bookworld, for posting an earlier version of this essay on his website: http://www.abcbookworld.com/ view_author.php?id=9I44. I am grateful to the reviewers of the manuscript for their helpful comments and corrections, and to the helpful staff at the Whistler Museum and Archives, at LAC, and at the Toronto Reference Library.

* Carole Gerson is a professor in the English Department at Simon Fraser University; with Jacques Michon, she co-edited volume 3 of History of the Book in Canada (2007). Her most recent book, Canadian Women in Print, I750I9I8 (Wilfrid Laurier University Press, 20I0) won the Gabrielle Roy Prize for Canadian literary criticism awarded annually by ACQL/ALCQ.

2 Carole Gerson, ed., Vancouver Short Stories (Vancouver: UBC Press, 1984).

3 Clipping, Alex Philip fonds, Whistler Museum and Archives. 


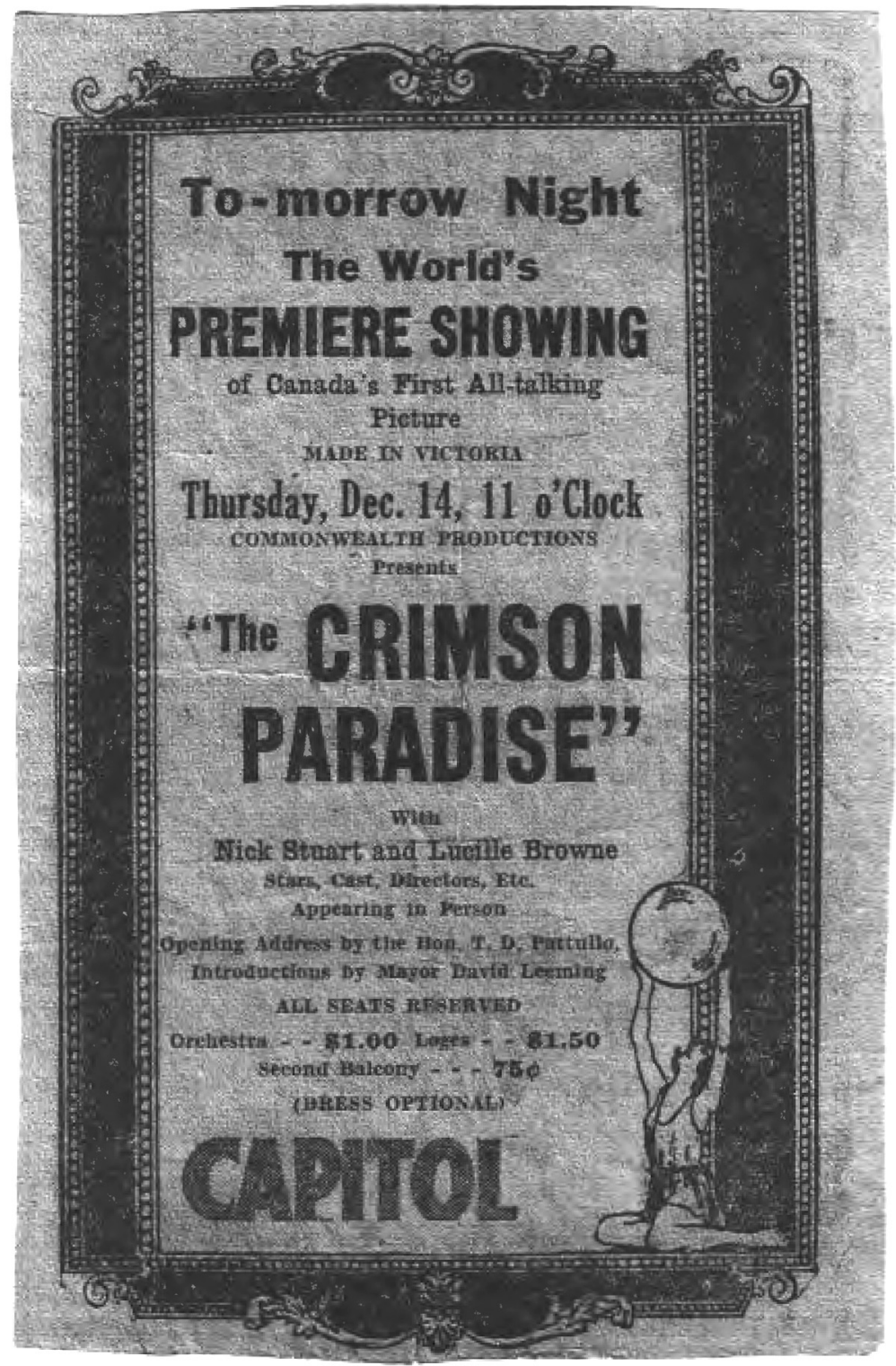

Figure I. Clipping, Philip fonds, Whistler Museum and Archives. Reproduced courtesy of the Whistler Museum and Archives. 
Founded in Ottawa in 1924 by Henry C. Miller, the Graphic Press has been canonized in Canadian book history as a brave nationalist venture that attempted to alter the nature of early twentieth-century publishing by producing books that were entirely made in Canada. ${ }^{4}$ During its brief existence (1924-32), under its various imprints the press issued fewer than roo titles representing different genrespoetry, history, fiction, travel, children's books, and reference works-all penned by Canadian authors, most of whom were based in Ontario. Alongside work by well-known writers such as W.A Deacon, Madge Macbeth, Raymond Knister, and Frederick Philip Grove, Graphic produced some long-forgotten books whose primary interest today is to illustrate the mindset of their time. While many of its titles have modest claims to literary merit, few are as deliberately sensational as those by Alex Philip. How Graphic came to publish Philip remains a mystery, given Philip's isolation on the west coast and lack of apparent connection with any of Graphic's authors or editors.

American-born Alex Philip (r882-1968) and his wife, Myrtle Tapley Philip (I89I-1986), are now mythologized as intrepid BC pioneers whose opening of Rainbow Lodge at trout-filled Summit Lake (now called Alta Lake) in 19I5, following the arrival of the PGE railway in 19I4, initiated tourism in the Whistler Valley, some is $\mathrm{km}$ north of Vancouver. Alongside the hard work of enlarging and managing the resort, which by 1948 had reputedly become the most popular honeymoon destination west of Jasper, ${ }^{5}$ the ever entrepreneurial Alex found sufficient time and energy to pen three novels which exemplify the clichés of Western romance transported to coastal and interior landscapes of British Columbia: The Crimson West (Toronto: Thomas Allen, 1925), The Painted Cliff(Ottawa: Graphic, 1927), and Whispering Leaves (Ottawa: Graphic, I93I). Philip’s first title became the basis of Canada's first all-talking film, The Crimson Paradise, made in Victoria in 1933 and now declared lost.

4 See Joyce M. Banks, "The Graphic Publishers Limited 1924-I932," National Library News 26.I (January 1994): 5-6; Edward St. John, The Graphic Publishers Limited I925-I932 (Ottawa: Historical Society of Ottawa, I992); Erik J. Spicer, "The Graphic Publishers Limited Ottawa, Ontario, Canada, I924-I932," Special Research for the Department of Library Science, University of Michigan, 1959; David B. Kotin, "Graphic Publishers and the Bibliographer," An Introduction and Checklist," PBSC XVIII (1979): 47-54.

5 "Whistler Yesterday to Today", http://whistler.ca/print/Visiting/About_ Whistler/History.php, viewed II/Io/2006 
Seeking to write best-sellers rather than literary fiction, Philip exploited BC settings by deploying nearly every stereotype of his age, many of which are now viewed as offensive. The plot of The Crimson West is furthered by nasty labour organizers, unpleasant immigrants from eastern Europe, and deceitful Natives. The villain of The Painted Cliff is a "crazed chieftain" with a gorgeous granddaughter who also loses her reason when deserted by her white lover. Whispering Leaves includes Mexicans and "Chinamen" who smuggle drugs and Asian labourers into the Cariboo region in the interior of British Columbia. It goes without saying that most of the women are amorous wimps in need of rescue. Surviving reviews indicate that Philip's fast-paced novels were generally well received as "pure fiction" that is "mighty good fiction," notwithstanding a few cavils about their amateurishness and strained credibility. ${ }^{7}$ The reviewer for the Montreal Star described The Painted Cliff as "a really excellent yarn" by "a veritable Rider Haggard of the Pacific Coast." He noted that "the mountains of British Columbia can be made into as good a backdrop for the bizarre as anything in South Africa" and requested that Philip further follow Haggard's example by providing a glossary of unfamiliar language, in this case Chinook jargon. ${ }^{8}$ While the Toronto Mail deprecated the "canned and machine-made" nature of Whispering Leaves, it conceded that "as many Canadians read this sort of thing, they may as well use the home-brewed brand."

Reviewers in British Columbia expressed no such reservations and praised Philip's literary initiative. Country Life in B.C. observed of The Crimson West that "In nothing that has been written has an author shown more genuine love of his subject than Mr. Philip exhibited in weaving the fabric of his great novel of the backwoods and pioneering days of British Columbia," ${ }^{\text {"Io }}$ a sentiment echoed in J. Butterfield's review of Whispering Leaves in the Vancouver Province. ${ }^{\text {II }}$ Quoted in many reviews of The Crimson West was a promotional flyer from its publisher, Thomas Allen (see Figure 2), that obligingly summarizes

6 Calgary Daily Herald, nd; ts in Philip fonds, Whistler Museum and Archives.

7 Noel Robinson, “The Star Window," Star, I6 Aug 1927, clipping in Philip fonds, Whistler Museum and Archives.

8 Montreal Star, 20 Aug 1927; ts in Philip fonds, Whistler Museum and Archives.

9 "Up Cariboo Road," Toronto Mail, Ir July ı931? clipping in Canadian Catalogue, Toronto Reference Library.

Io "The Crimson West," Country Life in B.C.,I4 no. 5 (May I926) I2.

II J. Butterfield, "The Common Round," Vancouver Daily Province; undated clipping in Philip fonds, Whistler Museum and Archives. 


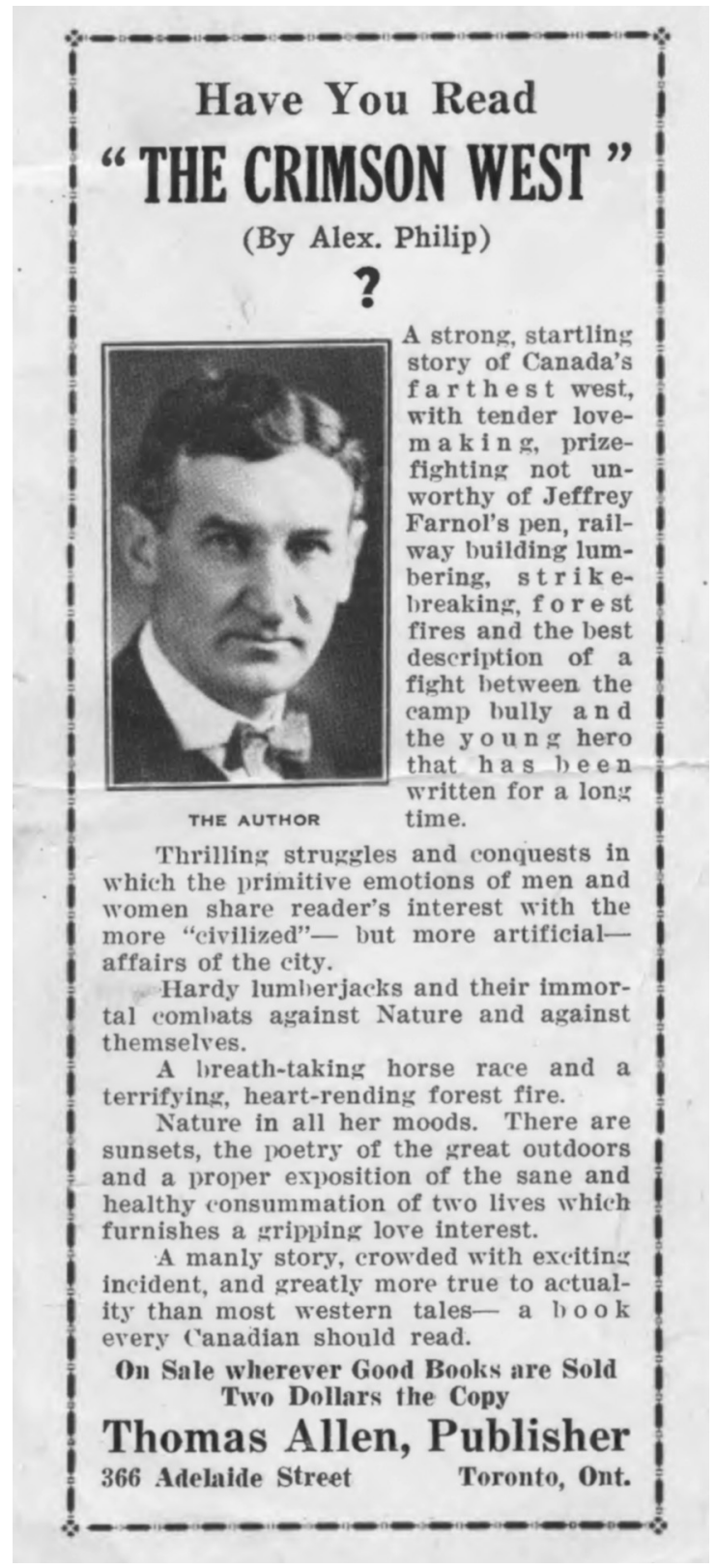

Figure 2. Publisher's Flyer, Philip fonds, Whistler Museum and Archives. Reproduced courtesy of the Whistler Museum and Archives. 
the many thrills the book has to offer: "A strong, startling story of Canada's farthest west, with tender love-making, prize-fighting not unworthy of Jeffrey Farnol's pen, railway building [,] lumbering, strike-breaking, forest fires, and the best description of a fight between the camp bully and the young hero that has been written for a long time. ... Nature in all her moods. There are sunsets, the poetry of the great outdoors and ... a gripping love interest. A manly story ... a book every Canadian should read." ${ }^{22}$ By contrast, Graphic's promotional material for its two Philip novels addressed a more genteel class of readers. Graphic's elaborate catalogue of I93I-32 (which proved to be the last gasp of a failing enterprise) describes Whispering Leaves as "a pleasing narrative" in which "villainy is unmasked and love comes into its own, bringing to a close this very pleasing story," and The Painted Cliff as "A rocky mountain romance of adventure and treasure trove." ${ }^{\text {'3 }}$

There is nothing in the sparse historical record to explain why Philip switched his publisher from the established commercial Toronto-based firm of Thomas Allen to the upstart Graphic house in Ottawa, especially as his contract with Allen contained a right of first refusal clause for his next book. ${ }^{\mathrm{I}}$ It could be that he was attracted to Graphic's nationalist mission, given that The Crimson West is dedicated to "Those Fortunates Who First Saw The Light Of Day In This Glorious Country, And With Whom Rests The Future Prosperity Of the Land of Their Birth-THE NATIVE SONS OF CANADA." Or it could be that Graphic approached Philip in an effort to broaden its readership and to enhance the meagre Western content of its list.

The first of Philip's Graphic books benefited from the press's distinctive aesthetic values: The Painted Cliff, bound in green cloth, featured a jacket by commercial artist Alan B. Beddoe as well as Graphic's signature Thunderbird endpapers (also designed by Beddoe, see Figure 3) and decorated capital letters for the first letter of the first word of each chapter. ${ }^{15}$ Whispering Leaves, which appeared when

I2 “Have you Read 'The Crimson West' (By Alex. Philip)?”flyer in Philip fonds, Whistler Museum and Archives.

I3 “Books, season 1931-32, by Graphic Publishers Limited," p 22; http://hpcanpub. mcmaster.ca/media/books-season-I93I-32-graphic-publishers-limited

I4 This contract is in the Philip fonds, Whistler Museum and Archives.

is The original dust jacket for The Painted Cliff may not be extant. It was one of the eleven titles that Graphic also issued under the Laurentian Syndicate imprint (Kotin, 48, 53) in a distinctive brown plasticated binding. Its front cover 


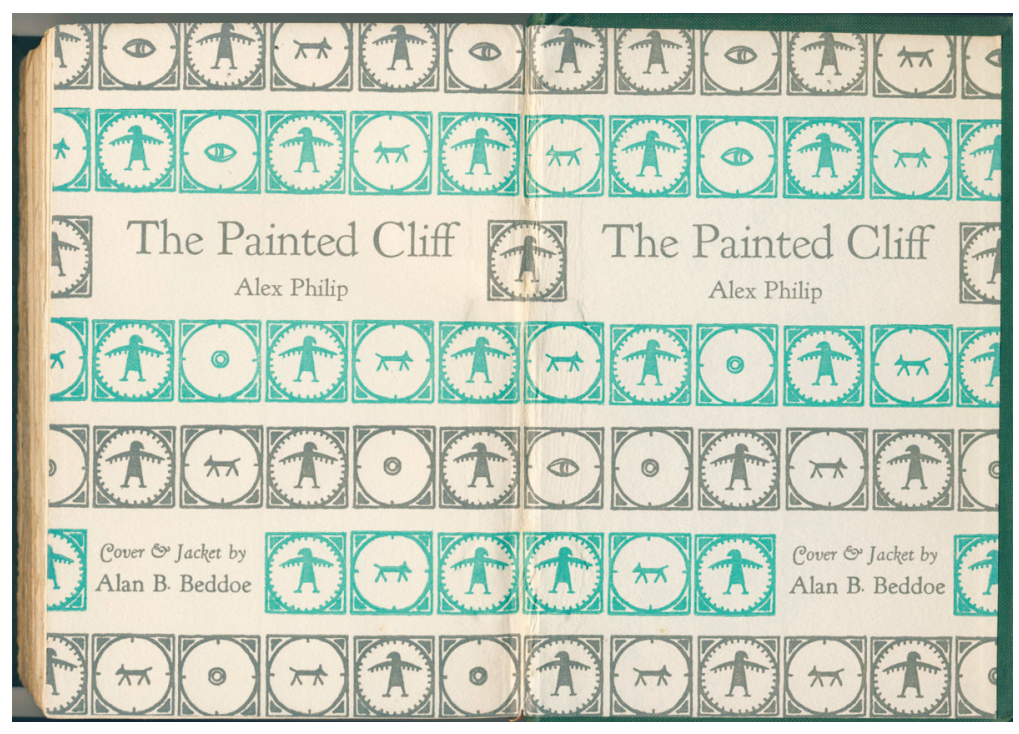

Figure 3. Endpapers, The Painted Cliff, copy owned by Carole Gerson.

Graphic was on its last legs, lacks the endpapers and finer typography and paper that characterized the books it produced during its prime, but it still bears a distinctive cover and dust jacket, whose elegant unsigned front and spine illustrations display vegetation that looks surprisingly tropical, even for BC (see Figures 4 and 5). Both books are considerably more attractive than Thomas Allen's exceedingly plain edition of The Crimson West, appropriately bound in crimson cloth, whose narrow margins and lack of decoration make it look like the run-of-the-mill entertainment that it indeed was.

The only surviving letters between Philip and Graphic, from the press's final days at the beginning of April 1932, concern Philip's desire to pursue Warner Brothers' interest in making a movie of Whispering Leaves, apparently the sole occasion when Graphic is known to have become involved with film rights. ${ }^{\mathrm{I}}$ While Philip

proclaims it an "All Canadian Edition," with a large Canadian Coat-of-Arms surrounded by nine miniature provincial coats-of- arms; the end-papers show the Peace Tower surrounded by coats-of-arms and maple leaves. In the copy I own, the title page is followed by a tipped-in full-page illustration of the coat of arms of British Columbia, printed in black on glossy yellow paper. 
Papers of the Bibliographical Society of Canada 49/I

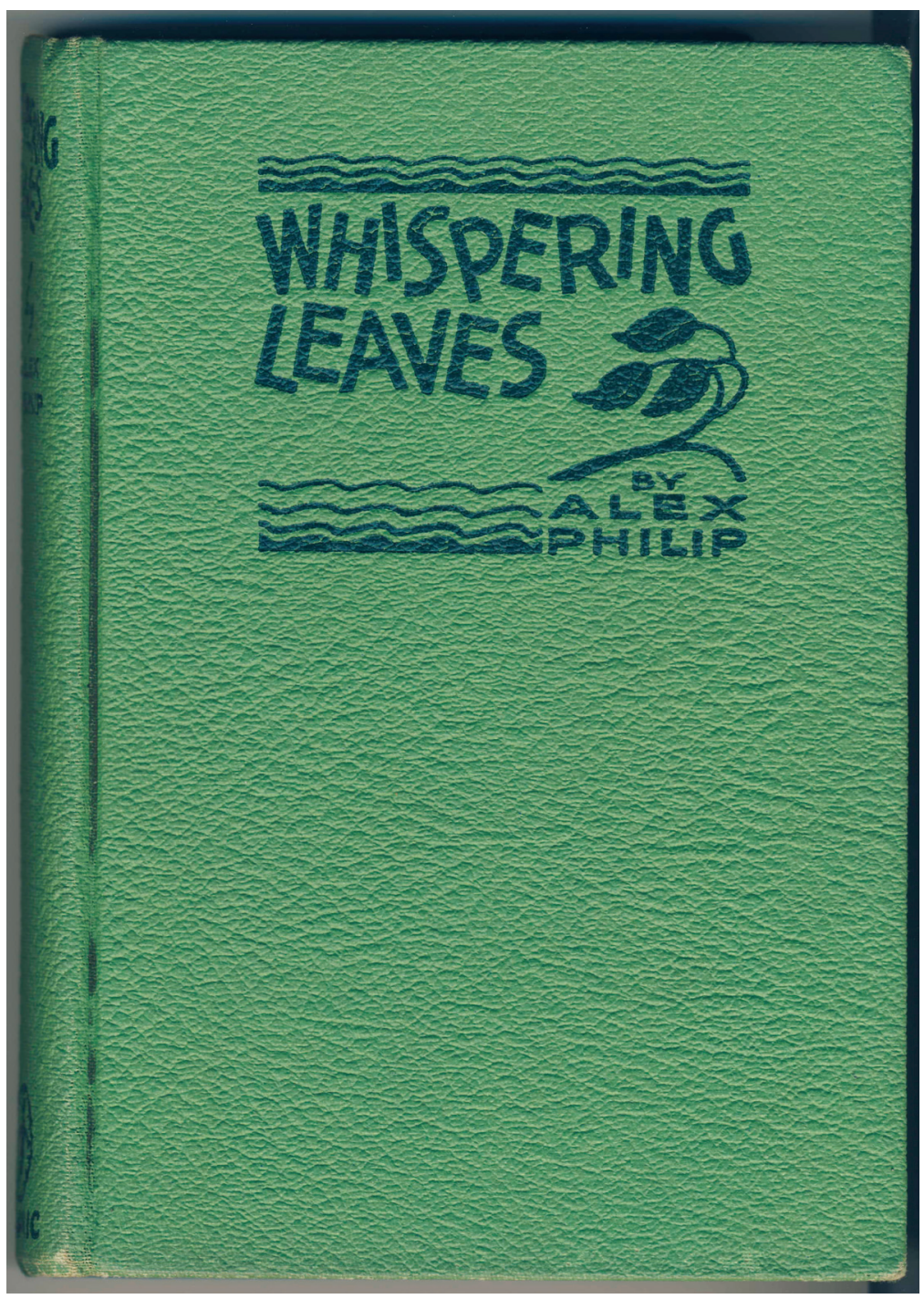

Figure 4. Front cover, Whispering Leaves, copy owned by Carole Gerson. 


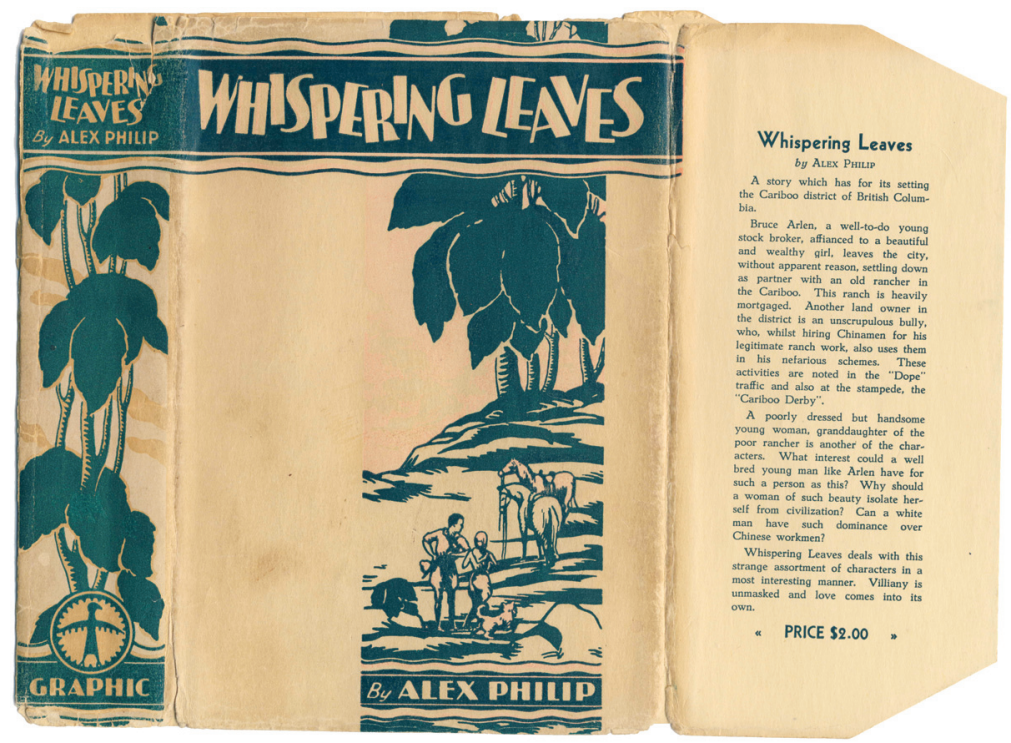

Figure 5. Dust Jacket, Whispering Leaves, copy owned by Carole Gerson.

agreed to have Graphic act as his agent, ${ }^{\mathrm{I7}}$ this prospect vanished upon Graphic's declaration of bankruptcy on 28 April 1932. Captivated by the prospect of becoming involved with the movies, Philip realized that with his two Graphic novels entangled in legal proceedings, his only available book was The Crimson West, whose film potential had been previously noted in a review: "Quite without subtleties, it is a vivid story, moving swiftly and easily on its simple way, and should be acceptable to a movie producer." ${ }^{\text {I8 }}$ Philip promptly sold the book's "Picture Rights" to Commonwealth Productions in Victoria, BC. ${ }^{\text {I9 }}$

This film production company had been created by Kenneth Bishop to take advantage of British laws in effect from 1928 to I938 that resisted American domination of the movie industry by requiring that up to $20 \%$ of the films shown in England be shot on British soil or within the Empire, and that at least $75 \%$ of the

I7 J. W. Robertson, Graphic Publishers, to Alex Philip, 4 April 1932, I8 April 1932; Canadian Authors Association fonds, LAC MG 28, I2, vol I.

I8 Unidentified clipping, 23 Jan 1926, Canadian Catalogue, Toronto Reference Library.

19 Philip to Mr. Kennedy, 29 Sept 1932, Canadian Authors Association fonds, LAC MG 28, I2, vol I. 
salaries be paid to British subjects. These regulations inspired many "quota quickies," ${ }^{20}$ including the fourteen feature films that Bishop produced from 1932 to 1937 , described by Canadian film historian Peter Morris as "competently made, if routine, B-movies." In 1938, Canadian productions (along with those from other parts of the Commonwealth) were eliminated from the British quota because most were indistinguishable from Hollywood movies. ${ }^{21}$ During the Depression, the city of Victoria envisioned itself as a centre of quota film production. Here The Crimson West was turned into a movie titled The Crimson Paradise; it credited Philip as author and was financed in large part by the wealthy Dunsmuir family, some of whom were cast in minor roles. The film's world premiere on I4 December 1933 was a lavish event, featuring speeches by the premier of British Columbia and the mayor of Victoria (see Figure 6). The Crimson Paradise played to full houses during its one-week run in Victoria, but because its creators had neglected to follow all the quota regulations and "too few members of the cast and crew were of British origin," 22 it failed to obtain distribution and vanished. Later recollections of several actors and other participants, gathered by a Vancouver reporter in 1973 on the fortieth anniversary of the film's opening, described The Crimson Paradise as a "real turkey. So lousy it was good." 23

Today, Alex Philip is better remembered in Canada's film history than in our literary history. His method of romancing the West by importing popular adventure conventions into a BC landscape chock full of local detail about railroads, logging, prospecting, and agriculture should be of interest to the historian, especially one who also wants to analyze Philip's construction of Anglo-CanadianAmerican masculinity (the rugged hero wins all the fist fights) within the framework of the gratuitous racism and sexism that characterized the common mindset of the r920s. But unlike many forgotten novels that merit resurrection for their appeal as period pieces, Philip's books contain so many offensive social stereotypes that I cannot recommend they be reissued for general readers, even though he occupies a niche in our cultural history as the first writer to fictionalize Whistler and other regions of $\mathrm{BC}$.

\footnotetext{
20 Peter Morris, Embattled Shadows: A History of Canadian Cinema I895-1939 (Montreal: MQUP 1978), I80-95.

2I Morris, I89.

22 Morris, I9I.

23 Aileen Campbell, "Our first film was turkey," Vancouver Province, I4 Dec 1973.
} 


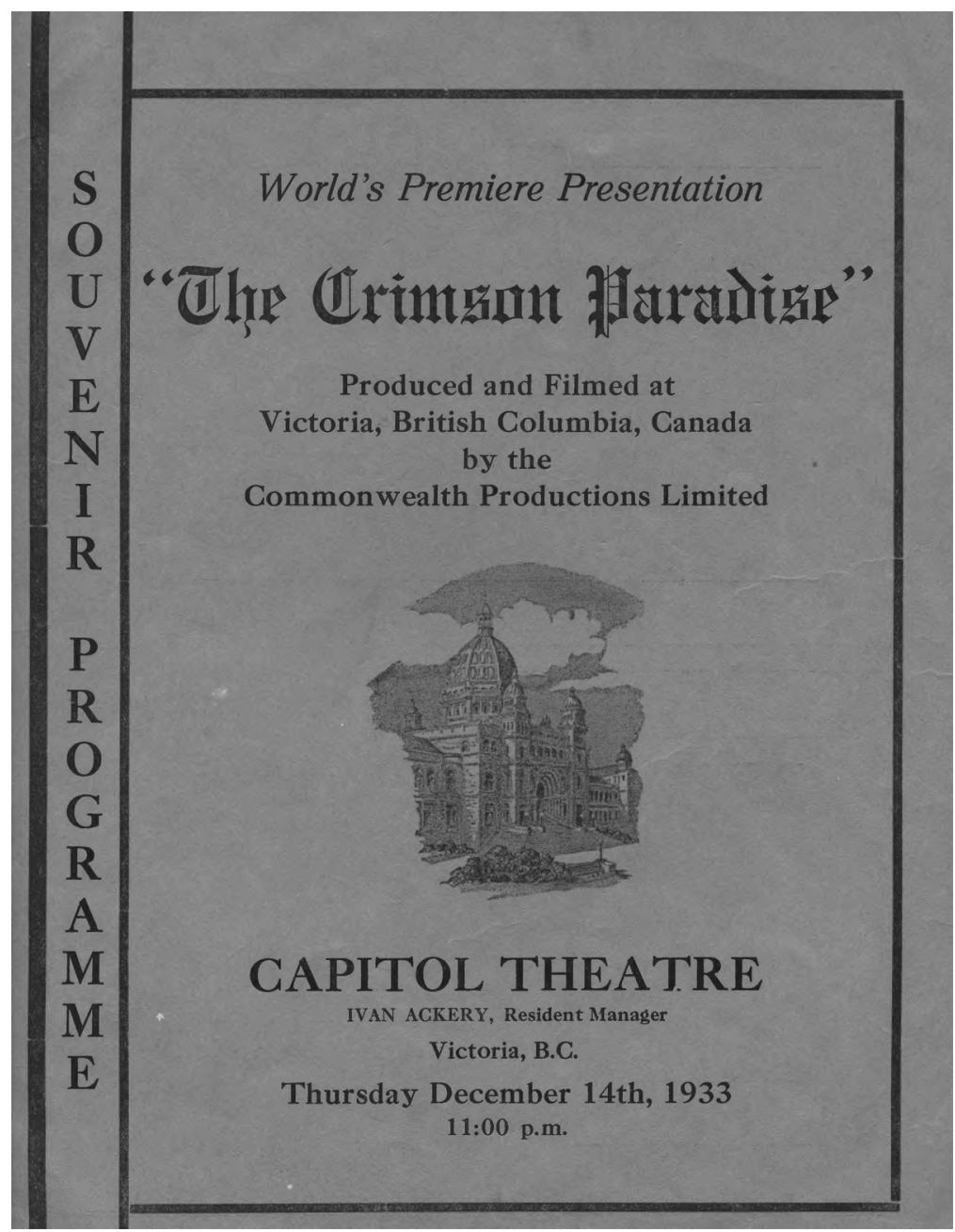

Figure 6. Cover, Souvenir Programme, Philip fonds, Whistler Museum and Archives. Reproduced courtesy of the Whistler Museum and Archives.

\section{SOMMAIRE}

Le compte rendu incomplet de la création et de l'accueil de trois romans de l'Ouest à sensation d'Alex Philip, publiés entre I925 et I93I, relate de fascinants détails sur les aspects peu connus de l'histoire du 
102 Papers of the Bibliographical Society of Canada 49/I

livre au Canada pour la raison que l'auteur publia deux livres chez Graphic Press à Ottawa et que l'un de ses romans jeta les fondements du tout premier film sonore au Canada. 